\title{
Malignant Tumor, Small Cell Type
}

National Cancer Institute

\section{Source}

National Cancer Institute. Malignant Tumor, Small Cell Type. NCI Thesaurus. Code C65154.

A malignant neoplasm characterized by the presence of small atypical cells. 